


\section{Published under the auspices of THE CENTER FOR JAPANESE AND KOREAN STUDIES, University of California, Berkeley}


THE FUTURE AND THE PAST 



\title{
The Future and the Past
}

$A$ translation and study of the

\section{Gukanshō,}

an interpretative history of Japan

$$
\text { written in } 1219
$$

\section{by Delmer M. Brown and Ichirō Ishida}

\author{
UNIVERSITY OF CALIFORNIA PRESS \\ BERKELEY • LOS ANGELES - LONDON
}


University of California Press

Berkeley and Los Angeles, California

University of California Press, Ltd.

London, England

Copyright (C) 1979 by

The Regents of the University of California

ISBN 0-520-03460-0

Library of Congress Catalog Card Number: 77-73493

Printed in the United States of America

123456789 
To Mary and Kikuko 
